\title{
TWO ASPECTS OF EARLY CHRISTIAN FAITH
}

\author{
Teresa Morgan*
}

Oriel College, Oxford

'Faith' is one of Christianity's most significant, distinctive and complex concepts and practices, but Christian understandings of faith in the patristic period have received surprisingly little attention. This article explores two aspects of what Augustine terms fides qua, 'the faith by which believers believe'. From the early second century, belief in the truth of doctrine becomes increasingly significant to Christians; by the fourth, affirming that certain doctrines are true has become central to becoming Christian and to remaining within the Church. During the same period, we find a steady growth in poetic and imagistic descriptions of interior faith. This article explores how and why these developments occurred, arguing that they are mutually implicated and that this period sees the beginning of their long co-existence.

The idea and practice of 'faith' have been central to Christianity for longer than its recorded history. ${ }^{1}$ No concept or praxis is invoked more often by followers of Jesus Christ, from the earliest letters of Paul onwards. Within a few years of the crucifixion, what we now call Christians were referring to themselves as 'the faithful'. By around the turn of the first

* Oriel College, Oxford, OX1 4EW. E-mail: teresa.morgan@classics.ox.ac.uk.

I am grateful to Alec Ryrie and the committee of the Ecclesiastical History Society for the invitation to speak at its 2019 Summer Conference, and to participants for their stimulating responses to the paper.

1 'Faith' is a placeholder for the complexity of Greek pistis, Latin fides and comparable terms in other languages of early churches, whose meanings include 'trust', 'trustworthiness', 'faithfulness', 'good faith', 'a pledge', 'a guarantee', a legal trust, a rhetorical proof, 'belief' and (among Christians) the 'new covenant', the content of doctrine and 'the faith'. 
century they were calling their organization 'the faith'. Throughout their history, Christians have appealed to faith more often, in more varied contexts, than adherents of any other ancient or modern cult or religion. ${ }^{2}$

It is therefore surprising how little detailed investigation there has been of how early Christians understood faith. In New Testament studies, certain aspects of pistis and its relatives - the lexicon we most often translate with the language of 'faith' or 'belief' - have been discussed extensively, including the meaning of the phrase pistis Christou in the Pauline corpus, and the use of pisteuein in the Gospel of John. ${ }^{3}$ With a few exceptions, such as the relationship between pistis and gnosis in the thought of Christian Platonists, and some aspects of Augustine's thinking about fides, understandings of faith in patristic writings have received very little attention. ${ }^{4}$ Until recently, there has been no historical study of faith in all its complexity at any period.

2 Teresa Morgan, Roman Faith and Christian Faith: pistis and fides in the Early Roman Empire and Early Churches (Oxford, 2015), 103. Why pistis language became so important to Christians so early remains uncertain. Calling people to trust in God may go back to Jesus himself: ibid. 350-2. Other Jewish groups in this period self-designate as (for example) wise, pure or faithful, so 'the [truly / properly] faithful' may have begun as a self-designation among Jewish Christians: ibid. 238-9. The absolute trustworthiness of God and Christ was part of early preaching at a time when trust, especially in people, was widely perceived as difficult and precarious: ibid. 36-122. Pistis language is unlikely, however, to have arisen to refer to believing in the resurrection (although it also came to mean that), because hoi pisteuontes and hoi pistoi are used interchangeably for 'the faithful', and the latter cannot mean 'believers': ibid. 239-41.

3 Ibid., especially 262-306, 347-93.

4 Notable exceptions include Oscar Cullmann's essay collection, La Foi et le culte de l'église primitive (Paris, 1963); Michael Schmaus, Alois Grillmeier and Leo Scheffcyzk, eds, Handbuch der Dogmengeschichte, 1/2a: Ignacio Escribano-Alberca, Glaube und Gotteserkenntnis in der Schrift und Patristik (Freiburg im Breisgau, 1974); Mark Elliott, 'Pistis Christou', in Michael F. Bird and Preston M. Sprinkle, eds, The Faith of Jesus Christ (Milton Keynes, 2010), 277-90; Oliver O’Donovan, 'Faith 
This article draws on a two-volume study in progress of Christian faith from the earliest Christian records to the fifth century. The first volume, Roman Faith and Christian Faith, investigates the treatment of pistis in the earliest Christian writings. The second traces the development of ideas and practices of faith from the second to the fifth century. What follows offers an overview of two strands in the evolution of faith which reflect the themes of institutionalization and inspiration, outlining how these strands develop over three centuries and how they are both distinct and interdependent.

The definition of faith most familiar to church historians and theologians is that of Augustine in On the Trinity (13.2.5). Augustine divides fides into fides quae ('the faith which is believed', the content of doctrine), and fides qua ('the faith by which it is believed', what takes place in the mind and heart of believers). This is not an ideal definition. It overlooks the meaning of pistis / fides (central in texts of the first and second centuries and still widely attested in the third and fourth) as the relationship of trust and faithfulness between God, Christ, and the faithful. It elides the meaning 'the faith', in the sense of the new covenant or the cult as a whole, and glosses over the complexity of what both Christian and non-Christian writers describe as taking place in the mind or heart. In Augustinian terms, however, this article investigates two aspects of fides qua: the attitude of belief that certain doctrines are true (what philosophers sometimes call 'propositional belief'), and the varied and colourful imagery through which Christians explore what it means to have faith in one's mind or heart.

Between the second and fourth centuries, both propositional belief and the imagery of interior faith become increasingly important to Christians. Propositional belief gradually becomes institutionalized, in the sense that affirming publicly that one believes certain propositions to be true becomes central to becoming and remaining Christian. The imagery of faith, meanwhile, becomes increasingly inspired, in the sense that it becomes an ever more

before Hope and Love', New Blackfriars 95 (2014), 177-89. These make significant contributions on specific questions, such as the evolution of creeds, the relationship between pistis and gnosis, and whether Christians sought to imitate the faithfulness of Christ. 
creative, varied, colourful and dynamic means to describe how people experience their interior life of faith. This parallel evolution, I suggest, is no accident, but constitutes part of the development and internal self-regulation of an increasingly complex and highly successful cult.

\section{THE INSTITUTIONALIZATION OF PROPOSITIONAL BELIEF}

Belief that certain things are true has been part of Christian thinking from as far back as we can trace. In 1 Corinthians 15: 3-11, for example, written in the early 50s, Paul tells the Corinthians, 'I handed on to you as of first importance what I also received: that Christ died for our sins in accordance with the scriptures; that he was buried; that he was raised on the third day in accordance with the scriptures ... so we preach and so you believed (ovँ $\omega \varsigma$

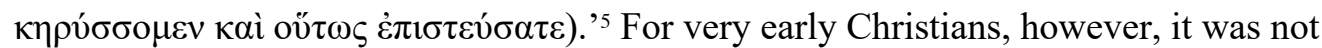
believing itself that admitted one to the community or kept one there. That took a further step: putting one's trust in God and Christ.

This distinction should come as no surprise. Under the Roman empire, almost everybody believed in the existence of a vast number of gods, heroes, divine men, spirits and demons. Nobody worshipped them all, not only because there were so many, but because many were specific to a particular locality or family or had a limited sphere of action. ${ }^{6} \mathrm{In}$ Christian contexts, the distinction between belief and religious commitment is less obvious in Greek than in English, because the verb Christians most often use for committing to God and

5 Transl. New American Bible.

6 Whether all Jews were strictly monotheistic in this period is debated, but believing (for instance) that multiple supernatural powers existed or that Elijah or Enoch was taken into heaven by God did not necessarily entail worship: Carey C. Newman, ed., The Jewish Roots of Christological Monotheism (Leiden, 1999); Larry W. Hurtado, One God, One Lord: Early Christian Devotion and Ancient Jewish Monotheism, 3rd edn (London, 2015). 
Christ, pisteuein, can mean both 'to believe' and 'to trust'. In context, however, it is normally clear which meaning is in play. Paul and other early writers undoubtedly expect members of their communities to believe certain things about God, Jesus Christ and God's action in the world, but when they call them to commit to Christ, they use pistis language in its sense of 'trust'.

Early Christian writing, in general, has limited interest in belief. Gospels, sayings collections, acts, apocalypses, letters, hymns, prayers, spells, oracles and sermons, all use pistis language, but nearly always in a relational sense. From around the turn of the first century, however, some writers become increasingly interested in belief, in two contexts: internal wrangles among the faithful about what to believe and debates between Christians and outsiders.

Even in these contexts, before the fourth century Christian writers do not typically discuss what they or others believe using pisteuein or credere. They prefer the language of thinking or knowing: nomizein, dokein, doxa, gnōsis, phronēsis, putare, noscere, opinio. ${ }^{8}$ It is only in the fourth century that Christians begin regularly to use pistis / fides language to refer to right belief. There are two likely reasons for the shift. The first is what we might call 'concept creep': Christians are so invested in pistis / fides language that, over time, they apply it to more and more aspects of the cult, and since 'belief' is a possible meaning of pistis and fides, it is there to be used. The second is the influence of Platonism.

Plato and his followers use pistis atypically, to refer to beliefs which are based on the evidence of this world, which in their view are unreliable compared with knowledge of the world of ideas. ${ }^{9}$ In the late Roman republic and early principate, however, we encounter a number of intellectuals (including Cicero, Plutarch and Origen's Celsus) influenced by

7 Morgan, Roman Faith, especially pp. 212-443.

8 This is why historians speak of 'orthodoxy' (right opinion) rather than 'orthopisty' (right faith or belief).

9 I am indebted to Mark Edwards for sharing his unpublished essay, 'Pistis and Platonism'. 
Platonism who are also deeply and explicitly interested in the nature and validity of mainstream cult. Plato's specialized usage of pistis creates a difficulty for them, because mainstream cult involves beliefs about the gods which are based on this-worldly evidence such as the fulfilment of prophecy and the recorded successes of the gods in healing people or ending wars. Many middle-Platonists are concerned to defend this-worldly reasons for believing certain things about the gods. Probably because of their debt to Plato, they often use pistis / fides language to do so. ${ }^{10}$ Early Christians, some of whom are also much interested in Platonism, are also keen to defend their cult against accusations that it is irrational. Some of these discuss Christian pistis in terms which are increasingly influenced by Platonism.

A few examples must suffice. Justin Martyr was born in about 100 CE. In his Dialogue with Trypho he describes how, as a young man, he investigated several schools of philosophy, including Platonism, before discovering and converting to Christianity. In the 150s Justin composed an apology, addressed to the imperial household, defending Christianity against contemporary accusations that it was immoral, irrational and seditious. Most of his defence of Christianity's rationality is couched in the language of thought and knowledge, but occasionally he uses pistis language, in very much the way that religious middle-Platonists use it, to suggest that there are this-worldly bases on which it is rational to believe:

We have received, by tradition, that God does not need the material offerings that human beings can give, seeing that he himself provides [us with] everything. We

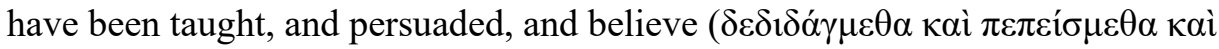

10 E.g. Plutarch, Moralia 165b, 359f-360b, 417a; idem, Life of Numa 4.3-4, Lucian, Icaromenippus 10; idem, Alexander 38, cf. Teresa Morgan, 'Doxa, praxis and Graeco-Roman Religious Thinking', in James Carleton Paget, Simon Gathercole and Judith Lieu, eds, Christianity in the Second Century: Themes and Developments (Cambridge, 2017), 200-13; John Wynne, Cicero on the Philosophy of Religion: On the Nature of the Gods and On Divination (Cambridge, 2019), 50-82. 


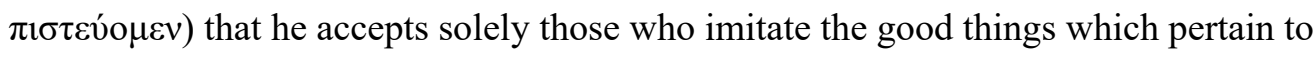
him: temperance, justice, and philanthropy ...

The coming into being at first was not in our power; and in order that we may follow those things that please him, choosing them by the powers of reason which he has

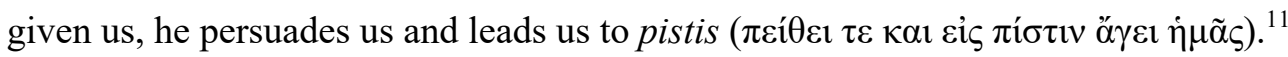

The idea that we please God by deploying the reason God has given us and imitating the divine virtues, and that we can do this because of the teaching we have received, parallels contemporary middle-Platonism (and, indeed, Stoicism). ${ }^{12}$ Justin does not define what he means by Christian pistis, but by linking it twice with persuasion he implies that it is the outcome of teaching applied to reason, and therefore that it is a cognitive function: something like belief.

A generation later, another apologist goes a little further. Athenagoras of Athens (born $c .133$ ) was also a philosopher, probably a Platonist, and a Christian convert. His Apology, also addressed to the reigning emperor and his son and dated to $176-7$, is a plea for equal rights. Like Justin, Athenagoras claims that Christians are moral people and loyal subjects of the emperor. Like Justin's, his Apology uses mainly the language of thought and knowledge rather than that of pistis. In one passage, however, he claims that Christians share many of their views with poets and philosophers, including that, ultimately, there is only one God. ${ }^{13}$ This being the case, it is outrageous that Christians, uniquely, are accused of atheism

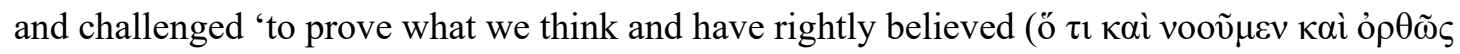
$\pi \varepsilon \pi 1 \sigma \tau \varepsilon v ́ \kappa \alpha \mu \varepsilon v)$, that there is one God' (7.27).

11 Justin Martyr, Dialogue with Trypho 10.60-1, 63. Translations are mine unless otherwise noted.

12 For example, Epictetus, Discourses 2.14.11-14; cf. Maximus of Tyre, Oration 27.7b-9d; Alcinous, Introduction to Plato 28.3-4.

13 For which Christians adduce the this-worldly evidence of prophecy: Athenagoras, Apology 7.28-9. 
'What we think and rightly believe' is a telling phrase. From the second century onwards, Christians were accused by critics of urging converts, 'Do not think, just believe'. ${ }^{14}$ Athenagoras insists that Christians both think and believe, echoing a phrase, pistis orthe, 'right belief', which goes back to Plato's Republic (10.601e). For Plato, 'right belief' has useful qualities but is inferior to knowledge. Later Platonists and writers who invoke Plato, however, use pistis orthē and doxa orthē approvingly, of right beliefs or opinions which are part of piety and which are appropriately held by those who are in a process of gaining knowledge of the divine. ${ }^{15}$ Athenagoras therefore implies that Christian pistis is part of a thought process about the divine which philosophers share and which leads to knowledge. To claim this, however, he has to present Christian pistis as belief rather than (for instance) as trust.

Almost a generation later again, Clement of Alexandria takes a more sustained interest in pistis: especially in the Protrepticus, addressed to non-Christians, and the Stromateis, addressed to Christians. This article cannot do justice to the complexity of Clement's thinking, but his contribution to the evolution of Christian understanding of pistis is decisive: partly because he is a serious philosopher with a particular interest in Platonism, who is deeply interested in the relationship between pistis and knowledge, and partly because he profoundly respects the letters of Paul, and wants to do justice to Paul's conviction that pistis brings human beings into their right relationship with God and stands at the heart of that relationship.

\footnotetext{
14 Origen, Contra Celsum 1.9.

15 Plutarch, Moralia 404b; Josephus, Against Apion 2.256.4; Anonymous Commmentary on Plato's Theaetetus, 2.52, 3.14, 3.16, 15.9; cf. Plutarch, Moralia 333b, 379b-c; John M. Dillon, '”Orthodoxy” and "Eclecticism": Middle Platonists and New-Pythagoreans', in idem and A. A. Long, eds, The Question of Eclecticism (Berkeley, CA, 1988), 103-25.
} 
Clement develops a multi-stage theory of pistis. ${ }^{16}$ At its simplest, it can be the kind of pre-rational trust or belief in things we take for granted which all human beings practise every day. ${ }^{17}$ At a more sophisticated level, it is a belief-response to things that are self-evident to reason. ${ }^{18}$ When, for example, in the gospels, we encounter the Word of God in Jesus Christ, Clement claims that we are encountering something self-evident to reason, to which we respond with pistis. ${ }^{19}$

Reason and pistis, for Clement, are both, ultimately, gifts from God, although both must be exercised by the faithful. ${ }^{20}$ The early stages of pistis make further rational thought and enquiry possible. By building on faith with investigation, we can begin to understand and to know God, and to judge the truth of claims about God. ${ }^{21}$ This leads to a further level of pistis: that which we have in the truth of something which has been demonstrated by reason. This highest level of pistis is very close to, if it is not identified with, gnosis, knowledge of God and even (in Platonic fashion) assimilation to God. ${ }^{22}$

In this summary, two points are of particular interest. Clement makes the most sustained early attempt to syncretize Christianity and Platonic philosophy, and in the process makes belief central to pistis. And he applies his understanding of pistis to his reading of an authoritative early writer, shifting the centre of gravity of Paul's pistis, in his interpretation,

16 See especially Eric Osborn, 'Arguments for Faith in Clement of Alexandria', Vigiliae Christianae 48 (1994), 1-24; Salvatore R. C. Lilla, Clement of Alexandria: A Study in Christian Platonism and Gnosticism (Oxford, 1971), Section 3, passim.

17 Clement, Stromateis 1.6.27, 2.9.45, 2.12.55. For Clement faith is always a free choice (e.g. ibid.

\subsection{9, 2.4.12.}

$18 \quad$ Ibid. 2.3.13.

19 Ibid. 2.11.48-9, 5.1.5-6.

20 Ibid. 1.7.38, 2.4.48.

$21 \quad$ Ibid. 2.2, 2.9-12, 2.4.14-15, 5.1.

22 Ibid. 7.10.55, 57, 2.22.126. 
from trust in God and Christ to belief. Clement's approach is summed up at the beginning of the Protrepticus, in an image of what Christ, the Word of God, does for the faithful: 'I am the door [Christ says], which we who seek to understand (noèsai) Christ must discover so that he may throw heaven's gates wide open to us. For the gates of the Word being intellectual (logikai), are opened by pistis [logikēe. ${ }^{23}$

Clement marks a new high-water mark in the philosophopoiesis of Christianity. He is not the last writer, however, to push the meaning of pistis towards belief. He is followed, among others, by his fellow Alexandrian and perhaps fellow school-member Origen, in his invective Against Celsus. ${ }^{24}$ Against Celsus was written in the late 240 s, in belated response to a late second-century work by Celsus, who, on the basis of internal evidence, was a Platonist and polytheist. From Origen's extensive quotations and citations of Celsus's Logos Alèthēs, 'True Doctrine', Celsus seems to have been extensively interested in pistis. His account is apparently that of a mainstream polytheist of his day. Pistis is both trust in the gods and belief, based on this-worldly experience, that certain things are true about the gods. ${ }^{25}$

Celsus detests Christians, who, he thinks, are cowards and charlatans who tell the vulnerable and ignorant, 'Do not ask questions, just believe' (1.9). In attacking Celsus, Origen tackles Celsus's concept of pistis explicitly. Unexpectedly, he largely agrees with it. Both writers hold that pistis can mean trust in the divine (1.19-21, 2.3-4), although Origen thinks that such trust is particularly suitable for the uneducated who cannot aspire to knowledge (6.13) ${ }^{26}$ Both hold that the pious should be able to prove that what they believe is reasonable,

$23 \quad 1.10 .2-3$.

24 Elsewhere, Origen does not match Clement's in pistis, but focuses more on the importance of knowledge (in which he is followed, notably, by the Cappadocians).

25 Teresa Morgan, 'Origen's Celsus and Imperial Greek Religiosity', in James Carleton Paget and Simon Gathercole, eds, Celsus in his World (Cambridge, forthcoming).

26 He assumes that even the uneducated hold trust-based beliefs: Gunnar af Hällström, Fides Simpliciorum according to Origen of Alexandria (Helsinki, 1984), 20-42. 
and Origen thinks Christians can. Their scriptures (by which he means the Jewish scriptures) are very ancient, and writings that have stood the test of time always bear credence (5.3). Many Christian doctrines (such as that God is one and good) are shared by contemporary philosophers (1.4-5). And Christianity is proved right by its consequences $(1.6,1.55)$ : we can believe in the incarnation, for example, because it has a beautiful effect on the character, implanting 'a wonderful meekness and tranquillity, and love of humanity, and kindness and gentleness' (1.67).

Origen, however, is also conscious of the limitations of what can be proven. If Christian preaching, he observes (1.62), had been based entirely on reason, then Christian pistis, like that of the philosophers, would have been belief in the wisdom of human beings rather than the power of God. Human reason is limited. We deal with its limitations by exercising pistis in another sense: that of rational risk. Every day - when we go to sea, get married or plant our fields - we trust that the things we do will turn out well. We do so in part on the basis of experience, but in part by taking a risk (1.11, cf. 1.31, 3.39). We trust in God in the same way, and this is acceptable (1.11), because risk-based trust is rational. There is always a gap between what we can infer from evidence and the uncertain future, and trust leaps into that gap. ${ }^{27}$ In a sense, here, Origen is talking of trust as a 'leap of faith', but not in the modern sense of the phrase. He advocates not deliberately non-rational trust or belief, but rational risk. By making this argument, however, Origen highlights the cognitive element even in trust, and shifts the centre of gravity of Christian pistis further towards believing.

All these writers are encouraged by interactions with non-Christians to present propositional belief as central to Christian pistis. At the same time, a different set of conflicts

\footnotetext{
27 The idea that trust is a rational risk is now a commonplace of trust theory in the social sciences, but this passage is highly unusual among ancient writings (cf. Arnobius, Adversus nationes 2.8), although his point, that we plant in the belief that we will reap, etc., casts trust as justified (experience-based) belief, not rational risk.
} 
pushes some Christians in the same direction: disputes among the faithful about their understanding of God and Christ.

It is worth noting that, as far as we can tell, in very early Christian communities, thinking something different from what one's neighbours think (about the nature of Christ, say, or the resurrection) may provoke argument, but there is no sign that it leads to formal expulsion from the community. ${ }^{28}$ The first people who are said, in so many words, to be expelled from a church for departing from a community's teaching and believing the wrong thing, are Valentinus and Marcion of Sinope in the mid-second century, according to Tertullian. ${ }^{29}$ Tertullian normally uses fides language in the mainstream Latin sense of 'trust' or 'loyalty'. Occasionally, however, usually when he is discussing Marcion, he invokes a more propositional meaning.

In Against Marcion, Tertullian introduces Marcion as 'a monster more philosophical than Christian. Because Diogenes the Cynic used to go about, with a lantern, at midday, looking for a real man, but Marcion has lost the God whom he had found by dousing the light of his faith (extincto lumine fidei suae)' (1.1.5). Marcion, in Tertullian's view, holds wrong views about God (he thinks that the God of Christians is not the God of the Hebrew Scriptures) and the nature of Christ (he is a Docetist). The 'light of [Marcion's] faith', the thing that ought to guide him to God, is therefore what he thinks is true about God and Christ. This makes right belief foundational to fides, but not necessarily identical with it. In On the Flesh of Christ, however, Tertullian goes further. Marcion holds that it is irrational to think of God as taking on human flesh. Tertullian objects that it is only irrational in human reason. He appeals to 1 Corinthians 1: 25: 'the foolishness of God is wiser than human

28 As opposed to idol-worship or incest, for example, which Paul already thinks are grounds for expulsion in 1 Cor. 10: 21 and 5: 4-5 respectively.

29 Writing several decades later: Tertullian, On the Prescription of Heretics 30.2. Judith Lieu observes that even in the mid-second century, claims of excommunications are anachronistic: Marcion and the Making of a Heretic (Cambridge, 2015), 396. 
wisdom'. He concludes: 'You [Marcion] are not a Christian, because you do not believe what, being believed, makes people Christians (non es Christianus, non credendo quod creditum Christianos facit)' (2.4). In this move, Tertullian identifies being a Christian with believing that certain things are true. ${ }^{30}$

These examples show something of how pressures on Christians from inside and outside the cult, together with their own interests and those of their interlocutors, edge some writers increasingly towards thinking of pistis, less as a relationship of trust or faithfulness between God, Christ and humanity, and more as belief. This in itself, however, does not constitute the institutionalization of belief. That requires a separate step: the development of creeds.

\section{INSTITUTIONALIZATION AND THE CREEDS}

The history of the creeds is a topic of much current debate to which this essay does not seek to contribute. It assumes only what is least controversial: that creeds develop out of baptismal interrogations, and that there are credible indications of their existence from at least the second century, though direct evidence comes, at the earliest, from the third.$^{31}$ If creeds begin

30 Eric Osborn, Tertullian, First Theologian of the West (Cambridge, 1997), 48-64; cf., probably a little later, Novatian, On the Trinity 1,11, emphasizing the importance of fides and credere in the truth (as opposed to heresy). Irenaeus, Against Heresies, occasionally clearly uses the 'belief' register of pistis / pisteuein (e.g. 5.20.1, fr. 36), but often refers to (for example) the 'kērygma and pistis' (e.g. 1.3.1) received, distinguishing the content of preaching (or 'preaching of the truth', e.g. 1.3.2, cf. 1.9.4) from pistis in it. The slightly later Refutation of All Heresies still prefers homologein, alètheia or alèthēs logos, for example, when speaking of what the faithful believe.

31 Apostolic Tradition 21.11-18: on reconstructions of the text, see Wolfram Kinzig, Christoph Markschies and Markus Vinzent, Tauffragen und Bekenntnis. Studien zur sogenannten 'Traditio Apostolica', zu den 'Interrogationes de fide' und zum 'Römischen Glaubensbekenntnis' (Berlin, 1999; Wolfram Kinzig, ed., Faith in Formulae: A Collection of Early Christian Creeds and Creed-Related 
life as baptismal interrogations, then they are always institutional: they define community membership. It does not follow, however, that they are always understood as propositional. The terms used of them suggest that, before the fourth century, they are not.

Early creeds are called ektheseis (expositions), mathemata (lessons) or, most often, symbola. A symbolon is a token, a guarantee, or any kind of official document, such as the token carried by imperial messengers. ${ }^{32}$ These terms suggest that early creeds are thought of as summaries of teaching which act as an identity marker. This is far from a new observation, but it has not been connected with the question what kind of faith is at stake when Christians use or invoke a creed. If creeds are identity markers, however, there are many aspects of Christian identity to be marked other than propositional beliefs, including trust in God, worship of Christ, obedience to teaching, acknowledgement of episcopal authority and presence at communal rituals. If creeds are summaries of teaching, that teaching may include much beside propositions, such as the narratives of the Scriptures and authoritative early Christian writings, stories about the saints or the history of the Church. We cannot assume that early Christians understood the identity they assumed and affirmed by saying early creeds as based on propositional beliefs, much less as defined by them.

Evidence of how creeds are put together and used, and the way their formally closest relations are used, also suggest that encoding propositional beliefs is not their earliest function. Liuwe Westra has argued that the hypothetical proto-Roman creed is constructed in part out of Christological acclamations, which at some point after about $150 \mathrm{CE}$ were fused

Texts, 4 vols (Oxford, 2017), 1: 153-61. All surviving versions of the earliest baptismal formulae use pisteuein / credere language.

32 This is also a meaning of pistis / fides. Symbola are used as tokens of membership in some mystery cults: Kinzig, Formulae, 1: 6, 61-144; Plutarch, Moralia 611d; Apuleius, Apology 56; Origen, Against Celsus 6.22. 
with a trinitarian baptismal formula. ${ }^{33}$ Comparative evidence suggests that this is a plausible picture. Acclamations are ubiquitous in classical antiquity, and many of them sound very like Christological formulae, and some not unlike Christian creeds:

Hail to Zeus the victor! $!^{34}$

Hear, O Israel, the Lord your God, the Lord is One! $!^{35}$

Great is Artemis of the Ephesians! $!^{36}$

Holy is God, the father of all, who is before the first beginning, whose purpose is accomplished by his own powers; who wills to be known, and is known by those who are his own; holy are you, who by your word have constructed all that is ... ${ }^{37}$

Throughout the ancient Mediterranean and Near East, acclamations act as identity markers and forms of worship. They imply beliefs, but their purpose is less to define or police beliefs than to affirm worshippers' commitment to a divinity. ${ }^{38}$

Acclamations also have a close relationship with the affirmations which are made when one person or group pledges allegiance to another. The baptismal question-and-answer in the Apostolic Tradition begins: 'Do you pisteueis [believe in, trust in, make your commitment to] one God, the Father Almighty, and his only-begotten son Jesus Christ, our

33 Liuwe H. Westra, The Apostles' Creed: Origin, History, and some Early Commentaries (Turnhout, 2002), 71-2.

34 Aeschylus, Agamemnon 174-5.

35 Deut. 6: 4.

36 Acts 19: 28.

37 Poimandres of Hermes Trismegistus, libellus 1.31.

38 T. Klauser, 'Akklamation', Reallexikon für Antike und Christentum 1 (Stuttgart, 1950), 213-33;

Charlotte Roueché, 'Acclamations in the Later Roman Empire: New Evidence from Aphrodisias', JRS 74 (1984), 181-99. 
Lord and our Saviour, and his Holy Spirit, Giver of life to all creatures'. The candidate responds: 'Pisteuo.' This formula is strikingly similar to the tripartite affirmation which new subjects make when they join the Roman empire:

'Are you the ambassadors and spokesmen sent by [for example] the Collatine people, to surrender yourselves and your people?'

'We are.'

'Is your people sovereign over itself?'

'It is.'

'Do you give yourselves and your people, your city, land, water, boundaries, shrines, utensils, and all things, divine and human, into the power of the Roman people?'

'We do.' 39

This is the Roman formula for deditio in fidem, the ritual by which new allies give themselves into a relationship of trust and loyalty with Rome. If Christians did not derive their idea of pledging pistis / fides to God, through a set of questions and answers, from the Roman empire, they surely accomplish something very similar by it, and it makes good sense that the resulting formula becomes known as a symbolon.

Creeds operate as identity markers, acclamations and affirmations or pledges of faith. Acclamations are also closely related to, and often embedded in, prayers and hymns, from the Homeric hymns to the Hebrew psalms to the offering prayer: 'My father was a wandering Aramean' ${ }^{40}$ Hymns and prayers commonly include, or allude to, stories about the god who is

39 Livy, 1.38.1-2, cf. Polybius, 36.4.2, Plautus, Amphitruo 258-9; see Morgan, Roman Faith, 98-9.

On the role of question-and-answer in admission to Roman Jewish communities, see Michel Dujarier, Le Parrainage des adultes aux trois premiers siècles de l'église (Paris, 1962), 82-9.

40 Deut. 26: 1-11. Kinzig suggests that Deut, 6: 4 and this passage are the nearest ancestors in the Hebrew Bible to Christian creeds: Formulae, 33-4. 
being worshipped or the past relationship between the god and his or her worshippers. It has occasionally been noted, though it has not been much explored, that creeds also make good sense as summaries of stories. Frances Young observes:

There is a sense in which creeds are not themselves a system of doctrine ... It's as though the essential content is ... a story ... Creeds 'are summaries of the gospel, digests of the scriptures. As Cyril of Jerusalem put it in his Catechetical Lectures (5.12), "Since not everyone can read the scriptures ... we summarize the whole teaching of the faith in a few lines".,41

Cyril is one of many sources attesting that much of the content of pre-baptismal instruction consisted of the contents of the Scriptures, full as they are of stories, acclamations, prayers and hymns, and that creeds were taught shortly before baptism as a summary of that teaching. ${ }^{42}$

If creeds emerge as summaries of teaching, summaries of stories, pledges, tokens of allegiance and acclamations, while Christian 'faith' language begins life focused primarily on trust and faithfulness rather than on belief as defining the divine-human relationship, gradually, Christians' disputes with each other and with non-Christians encourage them to make more and harder claims to knowledge and truth, and increasingly to use pistis / fides language of those claims. ${ }^{43}$ This processes reaches a crux in 325, at the Council of Nicaea,

41 Frances Young, The Making of the Creeds (London, 1991), 5.

42 Thomas M. Finn, Early Christian Baptism and the Catechumenate: West and East Syria (Collegeville, MN, 1992), 3-5; William Harmless, Augustine and the Catechumenate, rev. edn (Collegeville, MN, 2014), 35-130.

43 Accounts of the evolution of orthodoxy and of creeds still typically assume that belief and specific beliefs were crucial to Christians from the earliest formation of churches, but this overlooks the dominance of trust / faithfulness meanings of pistis / fides language in early writings, e.g. recently 
where the creed negotiated in response to Arianism includes, for the first time, material explicitly formulated to express what are claimed to be doctrinal truths. This creed is validated by the institutional authorities of the emperor and assembled bishops; it is used to baptize, and to assess the orthodoxy of existing community members. This is the moment when (at least in that form of Christianity endorsed by the emperor) Christians achieve 'orthopisty': propositional belief becomes institutionalized as definitive of being Christian. Significantly, it is after Nicaea that the phrase 'the true faith' (pistis alēthēs, vera fides) becomes widespread in our sources.

\section{AN EXPLOSION OF INSPIRATION: IMAGES OF FIDES QUA}

From the development of orthopisty, we turn to a very different aspect of early Christian faith. From the beginnings of Christian tradition, pistis had been imagined as active and dynamic. For Paul, it enables people to be forgiven and made right with God. ${ }^{44}$ In a saying of Jesus, it has the power to move mountains. ${ }^{45}$ With that exception, the early language of faith is not strongly imagistic, nor do early writings explore explicitly what faith is ${ }^{46}$ From the second

Wolfram Kinzig, 'From the Letter to the Spirit to the Letter: The Faith as Written Creed', in idem, Neue Texte und Studien zu den antiken und frühmittelalterlichen Glaubensbekenntnissen (Berlin, 2017), 293-310.

44 For example, Gal. 2: 16, Rom. 3: 21-6.

45 Matt. 21: $21=$ Mark 11: 23, cf. 1 Cor. 13: 2.

46 The apparent exception is Heb. 11: 1, but this is a description of how pistis works rather than a formal definition. 
century, however, especially in pastoral and devotional writing, we find a steady increase in imagery which explores what faith is and does. ${ }^{47}$

Given that faith has always been understood as leading to healing or release from sin, it is not surprising that some images are of healing or purification. ${ }^{48}$ John Chrysostom and Augustine, for example, both make much use of the idea of faith as medicine: 'the medicine of all the wounds of the soul', as Augustine calls it. ${ }^{49}$

One might think that the faith which is medicinal would be the content of doctrine. Occasionally it is, but more often it is the faith by which the faithful believe. Almost all images of faith are used to describe both how and what Christians believe. This convergence may seem surprising and potentially confusing, but there are good reasons for it. Images draw heavily on a relatively small group of authoritative early texts, especially the emerging canonical gospels. Christians are also keen to hold the different meanings of their faith language together. They imply that it is no accident that the act of trusting or believing in God and Christ, the new covenant and the content of doctrine are all called pistis / fides, and using the same imagery of them all is one way to express - if hardly to explain - their integrity.

The fact that faith can act as medicine for the soul does not necessarily imply that it is wholly under the believer's control. Between the second and fourth centuries, it becomes increasingly common to affirm that faith is a gift from God. This idea has roots in 1 Corinthians 12: 9, where pistis is a gift of the Spirit, and Galatians 5:22, where it is a fruit of the Spirit, and it becomes a significant theme, not least in fourth-century debates about grace

47 What follows focuses on images which appear multiple times in multiple (at least three and often a dozen or more) authors; these have the best claim to represent not just one author's idea but ideas that were widely shared and formed part of Christian mentalité.

48 Peter Chrysologus, Sermons 57.1 (faith is like a flaming coal taken from the alter to purify our lips).

49 Augustine, Letters 143.1, cf. John Chrysostom, Homilies on John 33.1; Paulinus of Nola, Poems $19.200-5$ 
and free will. The imagery of faith, however, does not polarize grace and free will as some argumentative writing does. More often, it seems to reflect a sense that faith is complex. It is given to Christians, but they have to accept it; it does something they cannot do for themselves, but they also have to exercise it. For John Chrysostom, for instance, faith is an oak tree planted in the soul which the faithful person must tend. ${ }^{50}$ For Ambrose, it is the drachma which the woman who has acquired it loses, and has to find again in order to save her soul. ${ }^{51}$

Another cluster of images focuses on the salvific function of faith, specifically its ability to elevate the soul from earth to God or heaven. 'Faith lifts the soul up from earth to God', says a second-century collection of gnomic sayings, The Sentences of Sextus (402). For Clement, in the Paidagogos (1.4.1), faith is a ship's rope by which we haul ourselves up to God, while for Ephrem the Syrian in one of his hymns on faith (84.1), the faith of the thief on the cross possesses him and raises him to paradise.

Most images of faith, however, focus less on heaven or the afterlife, and more on the role of faith in this life. This is a striking development. The earliest Christian writings say very little about what faith does, or what the faithful do with it, after their conversion, except that one must continue to be faithful. ${ }^{52}$ From the second century, however, Christians become increasingly interested in the role of faith after conversion: no doubt, at least in part, because they expect to have more life after conversion. As one late antique dice oracle says, 'Do not abandon the faith that is in your heart: it is helpful to you' ${ }^{53}$

Sometimes faith is described as foundational for the Church or for Christian life. In the second-century apocalypse The Shepherd of Hermas, Hermas is given a vision of the

\footnotetext{
$50 \quad$ John Chrysostom, Homilies on John 54.1.

51 Ambrose, Letters 7 to Iustus 2.

52 Morgan, Roman Faith, 220-2, 314-15, 336-8.

53 Vatican Coptic Papyrus 1.53, ET in Marvin W. Meyer and Richard Smith, Ancient Christian Magic: Coptic Texts of Ritual Power (Princeton, NJ, 1999), 253.
} 
Church as a tower which is in the process of being built. ${ }^{54}$ All the parts of the tower stand for God, virtues or various groups of Christians, and the whole structure is supported by seven women (3.8.2) who form an eclectic group of virtues. The first and most foundational of these virtues is Pistis, because, as the Church herself says, 'Through pistis the chosen of God are saved. ${ }^{55}$

The most widely used image of faith in this life, however, is that of a ship, which carries the faithful across the turbulent seas of life, bearing them up, weathering storms and bringing them safely into the harbour of heaven ${ }^{56}$ One might think that the faith we sail in would be 'the faith': the cult or the Church. Sometimes it is, but more often it is the faith of the faithful. Tertullian describes its action in On Idolatry (24):

[A]mid the reefs and inlets [of vice], the shallows and straits of idolatry, faith navigates, her sails filled by the Spirit of God; safe if cautious, secure if intently watchful. But for those who are washed overboard, there is a deep there is no swimming out of; those who run aground suffer inescapable shipwreck; for those who are engulfed ... every wave suffocates; every eddy sucks one down into hell. ${ }^{57}$

Without faith, says John Chrysostom, we are like people trying to cross the sea without a ship. They can swim for a while with their hands and feet but, as they get further out, they are

\footnotetext{
54 Vision 1, 2.1; 3, 2.4-5.

55 Cf. John Chrysostom, Catechetical Oration 1.19 (faith is the foundation on which everything else is built).

56 For example, Ephrem, Hymn on Faith 2.6, 49.6, 69.6; Cyril of Jerusalem, Catecheses 5.7;

Ambrose, On Faith 1.45-6.

57 We are used to the image of heaven as a palace, city or kingdom, but in these images it is always the harbour, surely reflecting that the most potent everyday Mediterranean experience of safety was of reaching harbour after a sea journey.
} 
swamped by the waves. ${ }^{58}$ For those who think of their spiritual journey as terrestrial rather than maritime, faith, according to Prudentius's Psychomachia (362-6), weaves new clothes for those setting out on their journey; it shines a light on the way; ${ }^{59}$ and, according to Paulinus of Nola, it strengthens the hearts of the faithful when they are afraid. ${ }^{60}$

As the faithful travel, faith plays several further roles in their lives. In two popular images, faith is guide and teacher. 'May pistis guide you in all good actions', say the Sentences of Sextus (166). ${ }^{61}$ A famous early example of pistis as both leader and teacher appears on the late second-century tombstone of Abercius of Hierapolis, in Asia Minor:

My name is Abercius, disciple of the holy shepherd [Christ] ... It was he who taught me trustworthy knowledge, and it was he who sent me to Rome, to see the queen of cities, and to see a Queen with golden robes and golden shoes ... Everywhere Pistis led the way; everywhere she fed me with fish from the spring, great and pure, caught by a holy maiden..$^{62}$

The queen with golden robes is probably the Roman church, while the fish which Pistis feeds to Abercius may well be fides quae, the content of doctrine. Pistis's feeding Abercius with

58 John Chrysostom, Homilies on John 33.1, cf. Augustine, Sermons on Matthew 75.2.

59 E.g. Oxyrhynchus Papyri 18.430; Ambrose, Hymns 4.25-8.

60 Paulinus of Nola, Poems 26.99-103.

61 Cf. Prudentius, Against Symmachus 2.91-3; Cyril of Jerusalem, Catecheses 4.6; Ephrem, Hymns on Faith 80.9.

62 W. Wischmeyer, 'Die Aberkiosinschrift als Grabepigramm', Jahrbuch für Antike und Christentum 23 (1980), 22-47, at 24-6; ET in Peter Thonemann, 'Abercius of Hierapolis', in Beate Dignas and R. R. R. Smith, eds, Historical and Religious Memory in the Ancient World (Oxford, 2012), 257-79, at 259. 
fish may also echo the feeding of the five thousand; if so, then Pistis here acts like Christ, a theme to which we will return.

On Christians' journeys, whether literal or metaphorical, faith is often a nurturing or a comforting presence. Two tombstones from late antique Gaul refer to her (in a very Roman expression) as alma fides: 'Alma Fides procured (conferre) for [someone whose name is lost] the height [or 'support'] of apostolicity, and when he died he went up to heaven. ${ }^{, 63}$ For Ambrose, in an evening hymn, 'watchful faith with cooling care' soothes the fevered brows of the faithful as they fall asleep. ${ }^{64}$

In more extreme situations, faith does more. Peter Chrysologus, in a sermon, describes the martyrdom of St Laurence on the gridiron. This horrible death, as Peter describes it, is made bearable with the help of faith:

Next, someone brought out the well-known gridiron for martyring Laurence ... by roasting him. He was bound fast by iron, but he regarded that gridiron of torture as a bed of rest ...

We admire his patience. Let us admire this as a gift from God. In this case his faith was not burning painfully in him: it was even consoling the man who was being roasted. Why was faith consoling him? Because it was keeping [him] faithful [to] the One making promises..$^{65}$

63 Françoise Descombes, Receuil des inscriptions chrétiennes de la Gaule, XV (Paris, 1985), 95, cf.

39.

64 Ambrose, Hymns 2.21-4.

65 Peter Chrysologus, Sermons 135; ET in St Peter Chrysologus, Selected Sermons; and St Valerian: Homilies, transl. George E. Ganss, FOTC 17 (Washington DC, 1953), 224. In the last sentence, quia fidelem tenebat promittentem, 'because it was keeping faithful the one making promises', is surely wrong, since God does not need to be kept faithful, while it would be odd to describe Laurence as making promises at the point of death. 
The divine gift of faith seems to take Laurence's pain away.

For Prudentius, in the Harmatogenia, when the soul of the faithful person finally reaches heaven, Faith is there, like Abraham or Godself, to clasp it to her bosom and let it unload all its troubles: 'Then, as the exiled soul returns to be reinstated in her heavenly country, white-haired Fides receives her to her bosom and comforts her nursling with tender affection, while [the soul] plaintively describes the many toils she has endured since she took up lodging in the flesh. ${ }^{96}$

In several of these passages, faith is more or less strongly personified. Before exploring personification a little further, however, it is worth summarizing the cumulative shape and effect of these images so far. Images of faith, among many authors and across many genres, describe faith as saving and changing the faithful. It acts as the foundation of their lives and carries them through life to a safe harbour. On the way, it supports them, comforts them and relieves their suffering. It teaches them and guides them, and, one way or another, ensures that eventually they reach heaven. These images convey vividly not only how important faith is, but how people imagine it as a dynamic force at the centre of their lives, and life itself as a project to which faith is essential. This makes faith extraordinarily precious, a theme which no-one captures better than Ephrem. In his hymns on faith, faith is a priceless pearl (16.6) which a merchant offers to his king as the most valuable thing he owns. It is a peeled grape (16.8), the most luxurious thing a vinedresser can offer his master. It is a beautiful bride (20.7), who should be carried in triumph through the marketplace.

The drama of these images should not mask the fact that for most Christians, most of the time, especially by the fourth century, life was probably not especially dramatic or dangerous. This, in itself, may be one reason why faith imagery develops as it does. It is often observed that by the fourth century Christians no longer expect the final cosmic battle or the return of Christ imminently, and persecution and martyrdom are no longer a regular risk. It is

66 Prudentius, Harmatogenia 852-5. Cana fides is another phrase with Roman origins. 
sometimes suggested that monasticism and asceticism develop in part as a response to this lessening of risk: as an alternative framework of life in which those with a particularly dramatic and dynamic sense of their life of faith can live it out. The imagery of faith, I suggest, does something similar for all the faithful. It creates a 'mental set' in which everyday life is a cosmic drama in which all the faithful can take part.

Most dramatically of all, faith helps the faithful to fight for their faith, and even fights for them: defending them against attack, bearing the brunt of their suffering in martyrdom, and seeing off the devil. It is in these roles that faith is most strongly personified. The idea that faith fights for the faithful has Christian roots in Ephesians 6.16, where pistis is a shield. ${ }^{67}$ In later writers, the shield often becomes a weapon. Armed with the word of faith, says Cyril of Alexandria in his Commentary on John, we destroy arguments and every obstacle to the knowledge of God, while Ambrose tells us that every martyr's faith is his sword. ${ }^{68}$ By the fourth century, Faith is sometimes the one wielding the weapon: Paulinus of Nola, Gregory of Nyssa and Augustine are among the writers of this period who talk about Faith going into battle on behalf of the faithful. No description of faith as a warrior, however, is more famous or influential than that of Prudentius in his poem, the Psychomachia.

67 Cf. Tertullian, On the Games 29, Gregory of Nyssa, Letter to Ablabius, lines 1-12, in Ekkehardus Mühlenberg and Giulio Maspero, eds, Gregorii Nysseni Opera, 5: Ad Ablabium, Quod non sint tres dei (Leiden, 2010), 37; John Chrysostom, Homilies on Genesis 46.2; Paulinus of Nola, Poems 15.145-52. The idea also has abundant parallels in Fides, the divine hypostasis of Jupiter, and other personified qualities which help, and sometimes fight for, human beings in Greek and Roman cult, myth and literature. Christian personification also owes something to the biblical personification of wisdom, although Jewish personification of wisdom seems to fall away in this period: Peter Schäfer, Mirror of His Beauty: Feminine Images of God from the Bible to the Early Kabbalah (Princeton, NJ, 2002), pp. $79-117$.

68 Cyril, Commentary on John 2.182, on John 1.32-3; Ambrose, Hymns 10.25 (on the martyrs of Milan); cf. Jennifer R. Strawbridge, The Pauline Effect: The Use of the Pauline Epistles by Early Christian Writers (Berlin, 2015), 57-73. 
The Psychomachia is an epic account of the war for the Christian soul between the virtues, led by Fides under the generalship of Christ, and a host of vices:

Fides first takes the field to face the doubtful chances of battle, her rough dress disordered, her shoulders bare, her hair untrimmed, her arms exposed ...

See, first Worship-of-the-Old-Gods [Vetera cultura deorum] ventures to match her strength against Fides' challenge, and strike at her.

But she, rising higher, smites her foe's head down, with its fillet-decked brows; lays in the dust that mouth that was sated with the blood of beasts, and tramples the eyes under foot, squeezing them out in death ...69

Prudentius's personifications have received abundant attention from both literary critics and theologians. ${ }^{70}$ The poem can be seen as the culmination of the classical theme of the gods at war which goes back to Homer, and the beginning of a long medieval tradition of large-scale allegory. Personification also offers a powerful mechanism for capturing all the meanings of faith (or hope, love or other key Christian qualities) under one helmet: Fides, for example, at different points in the poem, is a gift from God, the trust of the faithful, 'the faith' in the sense of the cult, and true doctrine. ${ }^{71}$ The personification of faith heightens that sense which has just

69 Prudentius, Psychomachia 21-33.

70 See especially Macklin Smith, Prudentius' Psychomachia (Princeton, NJ, 1976); Brenda Machosky, 'The Face that is not a Face: The Phenomenology of the Soul in the Allegory of the Psychomachia', Exemplaria 15 (2003), 1-38; Marc Mastrangelo, The Roman Self in Late Antiquity (Baltimore, MD, 2008); Ad Putter, 'Prudentius and the Late Classical Biblical Epics of Juvencus, Proba, Sedulius, Arator, and Avitus', in Rita Copeland, ed., The Oxford History of Classical Reception in English Literature, 1: 800-1558 (Oxford, 2016), 351-70.

71 Cf. Prudentius, Psychomachia 5-6 (gift from God), 868-74 (faith of the faithful), 29-39 ('the faith'), 726-827 (the true faith). 
been discussed, of faith as a force at the centre of Christian life, and life as a drama to which faith is crucial. ${ }^{72}$ Few life experiences can be more dramatic than hosting a bare-armed heroine inside you while she battles for your soul.

This article cannot do justice to Prudentius's personification of faith, much less to his practice of personification as a whole. It is, though, worth mentioning briefly two aspects of the former which add something to our understanding of the role of imagery in general to early Christian understandings of faith.

The Psychomachia begins with a prologue which traces God's command to the faithful to make war on the vices back to Abraham. Most of the poem consists of a series of duels between Fides, Pudicitia, Patientia, Mens Humilis and others, and their opposites, interspersed with lengthy speeches urging the reader to repentance and Christian life. Prudentius presents the battle as taking place within a human soul, and most commentators assume that the soul is doing battle with itself. A few have argued that the virtues and vices represent opposing forces in the battle between God and the powers of the world, or even that they are echoes of the deified abstractions of Greek and Roman cult. ${ }^{73}$ All these theories have something to commend them, but all leave questions unanswered.

The idea that there is tension between virtues and vices within the soul goes back to Plato, although philosophers do not tend to talk about progress in virtue as a war. Prudentius's terminology of virtue and vice is undoubtedly philosophical, but his picture of what is happening in the soul owes more to the Pauline epistles, in particular the idea that the faithful

72 In the Psychomachia an unusually large number of qualities is personified and portrayed as crucial to Christian life. Elsewhere, after faith, wisdom, truth, hope and love are the qualities most often personified. Logos is invariably identified with Christ and as such operates differently from other personifications.

73 E.g. Smith, Psychomachia, 126-31; Kenneth R. Haworth, Deified Virtues, Demonic Vices, and Descriptive Allegory in Prudentius' Psychomachia (Amsterdam, 1980); James J. Paxson, The Poetics of Personification (Cambridge, 1994), 66-7. 
are given various qualities as gifts by the Holy Spirit, and the idea that the faithful are fighting a war in themselves against the devil.

In the prologue (13-14), Prudentius says that the example of Abraham reveals that a bellicosus spiritus must do battle and overcome the monsters in our enslaved heart $(c o r){ }^{74}$ When all the vices have been expelled, Christ himself 'will enter the humble abode of the pure heart and give it the privilege of entertaining the Trinity' (prologue 59-63). Prudentius appeals to Christ to tell him 'with what fighting force the mind (mens) is armed' (5-6). He already knows the answer: the troops are the virtues, under Christ's leadership (11-20).

Prudentius's list of virtues does not exactly match any other such list (of which there are many in Greek philosophy, Hellenistic Judaism, and early Christianity), but nearly all of them are qualities familiar to Christians as either gifts or fruits of the Spirit in 1 Corinthians 12: 4-11 or Galatians 5: 22. Pistis, as has already been noted, appears in both lists. As has also been noted, the idea that qualities, which have been given to us, help us to fight the devil, appears several times in early epistles, most famously in Ephesians 6: 10-17. In those passages, the qualities the faithful put on are not their own virtues, but gifts from God which enable them to defend themselves in the cosmic war with the devil. The psychology of this poem therefore owes something to philosophy but rather more to the Pauline epistles. It is never fully articulated, no doubt because developing a theory of the soul was not Prudentius's prime concern, but the poem conveys a strong sense that the most important thing a Christian soul can do is to be receptive to Christ: to let Christ and his troops into itself to do their work. ${ }^{75}$ This implies a rather different psychology from the philosophically informed theories

\footnotetext{
74 Smith argues that mens, anima and spiritus are not exact equivalents but are often hard to differentiate: Psychomachia, 141-59. Many Latin writers use them in ways which are difficult, if not impossible to distinguish: Morgan, Roman Faith, 447-50.

75 This may be another Pauline idea in origin, if Prudentius had in mind Gal. 2: 20.
} 
which patrologists attribute (often rightly) to other writers. ${ }^{76}$ Prudentius has little or no sense that what matters in faith is knowledge, reason or the control of the best part of the soul over the rest of the soul or the rest of the self. He focuses on openness, receptivity and acquiescence to Christ.

As we have seen, Prudentius is by no means the only writer who personifies faith, especially when the life of faith is being imagined as a battle. In scenes of combat, the imagery of faith reveals not only something of these writers' psychology, but also some notable theology.

Poem 15 is one of several in which Paulinus celebrates the birthday of St Felix of Nola, who was believed to have been martyred during the Decian persecution or soon after. Here, he is describing how a martyr's faith holds out under persecution: 'Faith defeats [men armed with steel] through [its] awareness of heavenly truth; it measures the future life against immediate death, and it joyfully restores to God the mind which is victorious over the conquered body, and transports it to the delighted stars' (15.147-52). This is figurative but not perhaps a very developed personification; but Paulinus continues:

So [Felix] eagerly stood his ground like a wall against the savage foe. His blooming faith lent him fresh strength in his old age. Concentrating his mind on heaven, mindful of Christ, forgetful of the world, he bore God in his heart and his person was filled with Christ. His body now no longer contained him; he seemed a sanctified, greater being, and his eyes and countenance shone with heavenly glory. (15.171-6).

76 The study of patristic psychology in general would benefit from more attention to its scriptural and early Christian roots. 
It is a recurring theme in martyrologies that the martyr either puts on, or feels the presence of God or Christ, and that the presence of God with a human being causes shining. ${ }^{77}$ Here, however, we find Fides supporting Felix, alongside God and Christ. ${ }^{78}$

This is not an isolated passage. We have already encountered Faith behaving very like Christ on Abercius's tombstone and in a sermon of Peter Chrysologus, where she consoles St Laurence on the gridiron and takes away his pain. In his Hymn in Honour of St. Laurence, Prudentius goes even further. He describes how, in Christianity's battle with mainstream cult, 'Fides fought in arms, not sparing her own blood, for by death she destroyed death and spent herself to save herself ${ }^{79}$ This is a remarkable image. The language of salvation and the destruction of death unmistakably references the saving death of Christ. The phrase 'by death she destroyed death' virtually quotes 2 Timothy 1: 10. Here, therefore, Fides - either Laurence's faith, or perhaps 'the faith' - acts like Christ himself. She re-enacts Christ's saving death, and is imagined as continuing Christ's saving work on earth in the ongoing battle with idolatry.

In these passages, Faith constitutes a form of God's ongoing presence with the faithful, very much as do the risen Christ and the Holy Spirit. Either she enters people and inhabits them, like Christ or the Spirit, or she is with them, supporting them, as the risen Christ can be described as with the faithful and supporting them.$^{80}$ Theologically, this idea may come as a surprise to modern readers. We may wonder why Christians, who in this period already sometimes find themselves obliged to explain to outsiders in what sense they

77 Eusebius, Ecclesiastical History 5.123, 42; 8.7.2; The Martyrdom of Perpetua 18.2, The Martyrdom of Pionius 22.4.

78 In the event, Felix is not not martyred on this occasion, as Paulinus goes on to tell.

79 Crowns of Martyrdom 2.2.17-20.

80 Noted by Smith, Psychomachia, 158-9, but without connecting the point with earlier Christian thinking. This idea is probably not confined to personifications: it makes explicit an idea which is implicit in the imagery of medicine, teaching and guidance. 
have only one god, not three, feel it appropriate to cast faith as yet another form of God's presence with the faithful. Remarkably, writers of this period do not seem to regard this as a problem. One reason may be that the fourth century is an era in which intermediaries of various kinds proliferate between the divine and human spheres, notably in the cults of Mary the Bearer of God and the saints. Another reason may be that Faith never becomes a fullyfledged hypostasis of God, as Roman Fides is of Jupiter. I have yet to discover a Christian praying to her. ${ }^{81}$ She acts like Christ or the Spirit ad occasionem, to suit a writer's immediate needs, and then reverts to her usual status as an attitude, a relationship, a virtue, the body of doctrine or 'the faith'. This, indeed, is surely one of the attractions of imagery. It is highly flexible: it can help writers and their audiences think about the role of a quality like faith in their relationship with God, without involving them in complex and controversial questions of essence or personhood.

All these images and personifications testify to the central and honoured place of Christian faith in the divine-human relationship. It can be the sign and (in a non-technical sense) the substance of God's presence with the faithful. By having faith, the faithful have God, and God has them. In contrast with Christian thinking about belief, however, the imagery of faith, fluid and adaptable as it is, never becomes a focus of controversy in antiquity.

\section{CONCLUSION}

The idea of faith developed dramatically on several fronts between the second and fourth centuries, and it would be premature to draw firm conclusions about the concept and practice

81 Pseudo-Severian of Gabbala, in a sermon on faith, describes pistis as 'to be honoured and bowed down to in silence', in terms (timōmenon, proskynoumenon) which can be used of worship, but may not be intended so strongly here: Kinzig, Formulae, 2: 22-4. St Faith originates as a human martyr of the late third or early fourth century, although later she is sometimes confused with personified Faith. 
as a whole on the basis of this brief account of two of its strands. We can, however, offer some final reflections. It is tempting to infer a symbiosis between the increasing institutionalization of orthopisty (among many, if not all Christians) and the burgeoning imagery of faith. Certainly there is no sign that the wealth, variety and flexibility of the images we have explored constitute a rebellion against right belief, or a response to any perception of the imposition of orthodoxy as oppressive. Nor do these images, or their creators, show signs of wanting to challenge the structures or hierarchies of the Church. Most of the writers who develop the most colourful imagery are also establishment figures: bishops, aristocrats and (from the fourth century) supporters of Nicene orthodoxy. Rather, the parallel development of orthopisty and imagery points to an element of spontaneous selfregulation in a complex, increasingly sophisticated and very successful cult. Christianity recognizes faith as standing at its heart, and, in a period in which the faithful are being held to increasingly stringent standards of propositional belief, they are also offered a wealth of imagery to develop and shape their awareness of all the other things faith simultaneously means and does. Images ensure that faith is always recognized as both a gift and a responsibility; something which the faithful enact and which acts for them; a power which is with the faithful and in them, comforting and feeding them, teaching and fighting for them, and - if they do not scuttle the ship - eventually bringing them safely into God's harbour. 